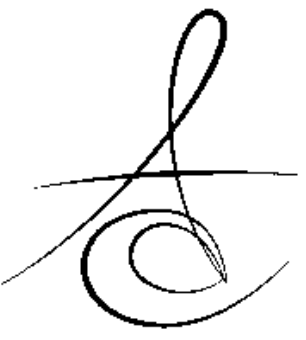

\section{EVALUATION OF 2 NICKEL-TITANIUM INSTRUMENT SYSTEMS IN SHAPING ROOT CANALS}

\section{KÖK KANALLARINI ŞEKİLLENDİRMESİNDE İKİ NİKEL TİTANYUM ALET SİSTEMİNİN DEĞERLENDİRİLMESİ}

\author{
Dr. Şenay YAŞAR*
}

\author{
Prof.Dr. Cumhur AYDIN*
}

Makale Kodu/Article code: 3632

Makale Gönderilme tarihi; 11.04 .2018

Kabul Tarihi: 16.10 .2018

\section{ABSTRACT}

Aim: To evaluate root canal enlargement following mechanical shaping using 2 nickel titanium rotary systems in simulated curved canals.

Materials and Methods: Thirty simulated canals in resin blocks were divided into two experimental groups, each comprising 15 resin blocks, and prepared with Twisted files (TF) and RaCe rotary files using crown-down technique. Preoperative and postoperative photographs, taken using a digital camera, were superimposed and aberrations were recorded. The amount of resin removed was measured at 11 different points, beginning at the apical terminus of the canal. Instrument failure, outer and inner width measurements, transportation rate, and centering ability were recorded on each central canal path and differences between groups were statistically analyzed using Student's t test.

Results: No instrument fracture occurred during preparation. RaCe instruments removed more material from the outer canal walls in the apical section ( $p<$ 0.01 ) and from the inner canal walls in the middle section ( $p<0.01$ ) of the canals compared to TF. However, canals prepared with TF instruments resulted in less transportation $(p<0.05)$ in the middle section. No significant differences were found between the two groups in terms of centering ability in apical, middle, or coronal sections. ( $p>0.05$ ).

Conclusions: RaCe instruments removed more resin from the outside of the apical curvature and from the inner side of the coronal curvature compared to TF. In addition, mean transportation amount was signifycantly high for RaCe in middle section (i.e., coronal curvature). Regarding canal centering ability, however, both instruments retained original canal geometry and performed similarly.

Key words: Twisted File, RaCe, Curved root canals, Canal transportation, Centering ability, $\mathrm{Ni}-\mathrm{Ti}$ rotary systems

\section{ÖZET}

Amaç: Simüle edilmiş eğri kanallarda 2 nikel titanyum döner alet sistemi kullanılarak mekanik şekillendirme sonrası kök kanal genişlemesinin değerlendirilmesi.

Gereç ve Yöntem: Reçine bloklardaki otuz adet simüle edilmiş kanal, her biri 15 adet rezin bloğu içeren iki deney grubuna ayrıldı ve Twisted files (TF) ve $\mathrm{RaCe}$ döner eğeleri kullanılarak crown-down tekniğiyle şekillendirildi. Bir dijital kamera kullanılarak çekilen preoperatif ve postoperatif fotoğraflar çakıştırıldı ve sapmalar kaydedildi. Kaldırılan rezin miktarı, kanalın apikal sonlanmasından başlayarak 11 farklı noktada ölçülmüştür. Her bir kanal yolundaki dış ve iç genişlik ölçümleri, transportasyon oranı, merkezde kalma yeteneği ve alet kırığı kaydedildi ve gruplar arasındaki farklar Student t testi kullanılarak istatistiksel olarak analiz edildi.

Bulgular: Preparasyon sırasında alet kırılması meydana gelmedi. RaCe eğeleri TF'e kıyasla kanalların apikal kısımdaki dış kanal duvarlarından $(p<0.01)$ ve orta kesitindeki iç kanal duvarlarından $(p<0.01)$ daha fazla materyal kaldırdı. Ancak, TF eğeleriyle hazırlanan kanallarda orta kısımda daha az transportasyon görüldü $(p<0.05)$. İki grup arasında, apikal, orta veya koronal kesitlerde merkezde kalma yeteneği açısından anlamlı fark bulunmadı ( $p>0.05$ ).

Sonuçlar: $\mathrm{RaCe}$ eğeleri TF'e kıyasla, apikal kurvatürün dışından ve koronal kurvatürün iç kısmından daha fazla rezin kaldırmıştır. Ek olarak, ortalama transportasyon miktarı orta kısımda RaCe için anlamlı derecede yüksekti (yani koronal eğrilik). Bununla birlikte kanalın merkezinde kalma yeteneği ile ilgili olarak, her iki enstrüman da orijinal kanal geometrisini korudu ve kanalı benzer şekilde şekillendirdi.

Anahtar kelimeler: Twisted File, RaCe, Eğri kök kanalları, Kanal transportasyonu, Merkezde kalma yeteneği, Ni-Ti döner alet sistemleri

\footnotetext{
* Department of Endodontics, Gulhane Dentistry Faculty, University of Health Sciences, Ankara.

${ }^{* *}$ Department of Endodontics, Faculty of Dentistry, Istanbul Medipol University, Istanbul.
} 


\section{INTRODUCTION}

The main objective of root canal preparation is to shape and clean the root canal system effectively while preserving its original shape and curvature and the position of the apical foramen. ${ }^{1} \mathrm{~A}$ number of procedural iatrogenic errors, such as zip, perforation, ledge formation, apical transportation, or deviation from the original canal pathway ${ }^{1}$ can occur when shaping curved canals. The original shape of curved root canals is better preserved when they are prepared with flexible nickel-titanium (NiTi) files instead of stainless steel files. ${ }^{2}$ The centering ability of $\mathrm{NiTi}$ files is better than that of stainless steel files and, consequently, their root canal transportation is reduced. ${ }^{3}$ However, it has been shown that the design features and method of manufacturing might significantly affect the clinical performance of $\mathrm{NiTi}$ rotary instruments. ${ }^{4}$ Hence, a constant search for better performance in terms of the quantity of material removed from the root wall concurrent with faithful adherence to the original shape of the root canal is progressing through introducing new methods of manufacturing NiTi rotary instruments. ${ }^{5,6}$ Recently, several new endodontic NiTi systems have been developed with different characteristics, such as: cross-sectional shape; taper; number and helical angle; kinematics; in addition to changes in metallurgy properties to enhance the mechanical properties of NiTi instruments. ${ }^{7,8}$ Two NiTi systems have been highlighted in the market. One is Twisted File (TF; Orange, CA, USA), with three unique design features, the R-phase heat treatment, twisting of the metal, and special surface conditioning (deoxidation). These processes significantly increase the instrument resistance to fracture, provide greater flexibility, and increase canal centering ability. ${ }^{9,10}$ The other system is the Reamer with Alternating Cutting Edges (RaCe; FKG Dentaire, La Chaux-de-Fonds, Switzerland). The Race system consists of instruments that are manufactured from a conventional austenite NiTi electropolishing surface treatment and have a noncutting safety tip and triangular cross sectional design with alternating cutting edges that enhance cutting efficiency while producing a more centered canal shape. ${ }^{11-13}$ These two systems were selected for this study because they are recently developed and according to the manufacturer, both systems have improved flexibility, showing less transportation during the chemomechanical preparation. Furthermore, the shaping ability of this system in curved canals has yet to be fully characterized. Therefore, this study was conducted to compare the changes in canal curvature after canal preparation by using TF and RaCe rotary systems. The null hypothesis tested stated that there is no difference among these $2 \mathrm{NiTi}$ rotary instruments with respect to change in canal curvature.

\section{MATERIALS AND METHODS}

Thirty simulated root canal blocks made of clear polyester resin (Endo Training Bloc-.02 Taper, Dentsply Maillefer, Ballaigues, Switzerland) were used to prepare root canals using TF (SybronEndo, CA, USA) and RaCe (FKG Dentaire, La-Chaux-de-Fonds, Switzerland) instruments. The taper and the diameter of simulated canals had the ISO standard size \#15 and a $40^{\circ}$ curvature aligned with the Schneider method. ${ }^{14}$ The entire block was $16 \mathrm{~mm}$ long with a canal orifice $13 \mathrm{~mm}$ away from the apex. The canals were $13 \mathrm{~mm}$ long in total length, composed of a $5 \mathrm{~mm}$ straight part and an $8 \mathrm{~mm}$ curved part. The simulated root canals were randomly divided into two groups which were prepared using either the TF or the RaCe systems ( $n=15$, for each group). All canals were prepa- red by a single operator with extensive experience in both systems. The measurement of the canals was carried out by another researcher who was unaware of the experimental groups. A Dentaport Tri Auto ZX Module (J.Morita Mfg. Corp, Kyoto, Japan) was used to operate both instruments at $500 \mathrm{rpm}$. All canals were prepared with a crown-down technique following the TF and RaCe manufacturers' instructions. The canals were prepared to a working length of 16 $\mathrm{mm}$ and a size of \#25, 0.04 taper. Glycerin was used as a lubricant with each instrument during preparation. Irrigation was performed with distilled water, after each instrument size, totaling $10 \mathrm{~mL}$ per canal for all groups. Instruments were replaced with new ones after two canal preparations.

\section{Canal preparation}

Group A. TF instruments were used in a crowndown manner according to manufacturer's instruct tions. The sequence of instrument usage was:

1. \#10 K-File (used to create a glide path).

2. $0.08 / \# 25$ instrument to $10 \mathrm{~mm}$.

3. $0.06 / \# 25$ instrument to $12 \mathrm{~mm}$.

4. $0.04 / \# 25$ instrument to $16 \mathrm{~mm}$ (full working length). 
Atatürk Üniv. Diş Hek. Fak. Derg.

J Dent Fac Atatürk Uni

Cilt:29, Sayı:3, Yıl: 2019, Sayfa, 400-406

Group B. RaCe instruments were used in a crown-down manner according to manufacturer's instructions. The sequence of instrument usage was:

1. \#10 K-File (used to create a glide path).

2. $0.10 / \# 40$ instrument to $8 \mathrm{~mm}$.

3. $0.08 / \# 35$ instrument to $10 \mathrm{~mm}$.

4. $0.06 / \# 25$ instrument to $12 \mathrm{~mm}$.

5. $0.02 / \# 25$ instrument to $16 \mathrm{~mm}$. .

6. $0.04 / \# 25$ instrument to $16 \mathrm{~mm}$ (full working length).

\section{Assessment of canal preparation and analysis of data}

Each canal was photographed in a standardized manner before and after instrumentation using a charged coupled device (CCD) camera (Canon S2 IS, Canon, Tokyo, Japan). A composite image was produced from pre- and post-instrumentation images and superimposed using Adobe Photoshop software (Adobe Photoshop CS, Version 8.0, Adobe Systems Incorporated, San Jose, CA). Superimposition was aided by vertical and horizontal lines placed on the surface of the resin blocks (Figure 1 and Figure 2). The amount of resin removed from the inner and outer sides of the canal in 1-mm steps were measured one-dimensionally using the Image J 1.38 program with an accuracy level of $0.001 \mathrm{~mm}$ (National Institutes of Health public domain program; http://rsb.info.nih.gov/ij/download.html).

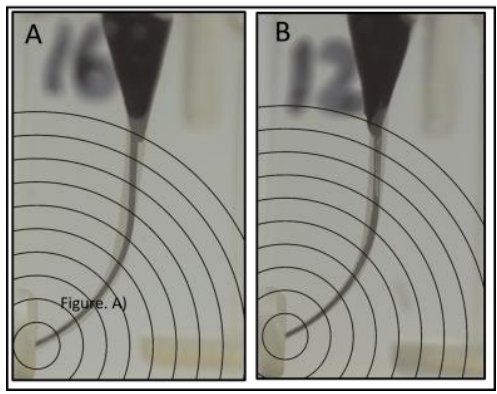

Figure 1. Preop and postop superimposed images (A Race; B Twisted Files)

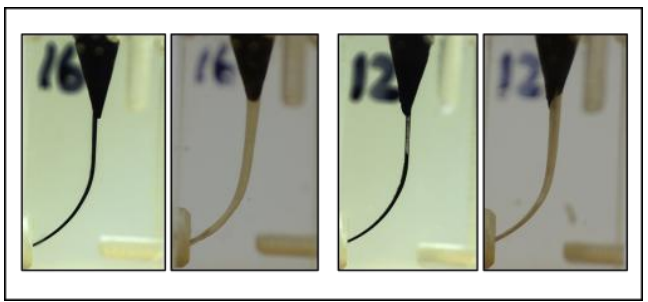

Figure 2. Preop and postop images (A Race; B Twisted Files)
YASSAR, ERŞAHAN, AYDIN

All measurements were collected at right angles to the surface of the canal. The first measuring point was the apical ending of the canal, and the last measuring point was $11 \mathrm{~mm}$ from the apical end, resulting in 11 measuring points at the outer and inner sides of the canal, for a total of 22 measuring points.

Different types of canal aberrations such as apical zip associated with elbow, ledge, perforation, and danger zone were assessed using superimposed images. These canal aberrations were defined according to the descriptions of Thompson and Dummer. ${ }^{15}$

Canal transportation (deviation of the axis after instrumentation) was calculated by substracting the amount of resin removed at the outer wall from the amount of resin removed from the inner wall. A positive result indicated transportation towards the inner canal wall. If a negative result is found, the direction of transportation was determined to be towards the outer wall.

The centering ability of the instruments was calculated by dividing the amount of resin removed at the inner or outer wall by that removed at the opposite wall; the lower value was considered as the numerator of the ratio. According to this, values closer to ' 1 ' indicate better centring ability. ${ }^{16}$

\section{Statistical analysis}

The Student $t$ test was conducted to explore a significant difference in mean degree of canal transportation and centering ability between the two systems. SPSS version 22.0 (IBM, USA) software was used for statistical analysis.

\section{RESULTS}

\section{Instrument failure}

No instrument fracture occured during the preparation of the curved canals.

The amount of resin removed from the inner and outer sides of the canal

The mean width of resin removed from the inner and outer side of the canals is shown in Table 1. TF and RaCe instruments removed almost the same amount of resin from the inner canal curvature in the apical section. However, RaCe removed more material from the outer canal curvature in the apical section. The difference between the groups was significant at $1 \mathrm{~mm}, 2 \mathrm{~mm}$, and $3 \mathrm{~mm}$ from the apex $(\mathrm{t}(28)=-6.50$, 
Atatürk Üniv. Diş Hek. Fak. Derg.

] Dent Fac Atatürk Uni

Cilt:29, Sayı:3, Yıl: 2019, Sayfa, 400-406

$\mathrm{p}<.01$ for $1 \mathrm{~mm}$; $\mathrm{t}(28)=-5.72, \mathrm{p}<.01$ for $2 \mathrm{~mm}$; $\mathrm{t}(28)=-3.34, \mathrm{p}<.01$ for $3 \mathrm{~mm})$.

TF and RaCe instruments removed almost the same amount of resin from the outer canal curvature in the middle section ( $4 \mathrm{~mm}$ to $8 \mathrm{~mm}$ ). Compared to TF, RaCe removed significantly more material from the inner coronal curvature starting at $4 \mathrm{~mm}$ through 7 $\mathrm{mm}$ from the apex $(\mathrm{t}(28)=-4.02, \mathrm{p}<.01$ for $4 \mathrm{~mm}$; $\mathrm{t}(28)=-4.10, \mathrm{p}<.01$ for $5 \mathrm{~mm}$; $\mathrm{t}(28)=-3.45, \mathrm{p}<.01$ for $6 \mathrm{~mm}$; $\mathrm{t}(28)=-3.53, \mathrm{p}<.01$ for $7 \mathrm{~mm})$. There was a similar difference at $8 \mathrm{~mm}$ but this difference was not statistically signicant $(\mathrm{t}(28)=-1.95, \mathrm{p}=.06$ for 8 $\mathrm{mm})$.

There were no significant differences between TF and RaCe instruments as each removed the same amount of resin from the outer surface of the canal wall in the coronal section. However, differences were observed at the inner surface of the coronal section of the root canal. RaCe removed significantly more material than TF at $10 \mathrm{~mm}$ from the apex $(\mathrm{t}(28)=-$
YAŞAR, ERŞAHAN, AYDIN

$2.28, \mathrm{p}<.05)$. The difference at $9 \mathrm{~mm}$ from the apex was not significant $(\mathrm{t}(28)=-1.70, \mathrm{p}=.10$.

\section{Canal Transportation}

The mean values for transportation after instrumentation at each section are shown in Table 2. In the coronal and apical sections of the canals, there were no statistical differences between the two groups for canal transportation. At the middle section of the canals (5 and $6 \mathrm{~mm}$ from the apex), the canals prepared by $\mathrm{RaCe}$ instruments had a larger mean value for transportation in the direction of the inner canal wall $(\mathrm{t}(28)=-2.60, \mathrm{p}<.05$ for $5 \mathrm{~mm}$; $\mathrm{t}(28)=-$ 2.44, $\mathrm{p}<.05$ for $6 \mathrm{~mm}$ ).

\section{Centering ability}

The centering ability (expressed by centring ratio) of each section is shown in Table 3. There were no significant differences between the two groups for centring ability in all sections.

Table 1. Mean material removed $(\mathrm{mm})$ and SD at the different measuring points after instrumentation of simulated canals

\begin{tabular}{|c|c|c|c|c|c|c|c|c|c|c|c|}
\hline \multirow[t]{2}{*}{ Twisted Fil } & \multicolumn{11}{|c|}{ Inner canal wall (mm from the apex) } \\
\hline & 0 & 1 & 2 & 3 & 4 & 5 & 6 & 7 & 8 & 9 & 10 \\
\hline Mean & 0,07 & 0,09 & 0,10 & 0,10 & 0,11 & 0,20 & 0,28 & 0,26 & 0,22 & 0,21 & 0,20 \\
\hline SD & 0,03 & 0,03 & 0,03 & 0,03 & 0,02 & 0,03 & 0,04 & 0,03 & 0,03 & 0,03 & 0,04 \\
\hline $\begin{array}{l}\text { RaCe } \\
\text { Mean }\end{array}$ & 0,07 & 0,09 & 0,10 & 0,11 & 0,16 & 0,26 & 0,33 & 0,31 & 0,25 & 0,23 & 0,23 \\
\hline SD & 0,02 & 0,03 & 0,02 & 0,02 & 0,04 & 0,05 & 0,04 & 0,04 & 0,04 & 0,04 & 0,05 \\
\hline \multirow[t]{2}{*}{$P$ value } & 0,56 & 0,50 & 0,93 & 0,65 & $* *$ & $* *$ & $* *$ & $* *$ & 0,06 & 0,10 & $*$ \\
\hline & \multicolumn{11}{|c|}{ Outer canal wall (mm from the apex) } \\
\hline Mean & 0,09 & 0,07 & 0,08 & 0,11 & 0,15 & 0,10 & 0,06 & 0,11 & 0,18 & 0,24 & 0,26 \\
\hline SD & 0,03 & 0,02 & 0,03 & 0,03 & 0,03 & 0,02 & 0,02 & 0,03 & 0,04 & 0,04 & 0,04 \\
\hline $\begin{array}{l}\text { RaCe } \\
\text { Mean }\end{array}$ & 0,10 & 0,13 & 0,15 & 0,16 & 0,14 & 0,10 & 0,06 & 0,11 & 0,19 & 0,25 & 0,29 \\
\hline SD & 0,05 & 0,03 & 0,03 & 0,04 & 0,03 & 0,03 & 0,03 & 0,04 & 0,03 & 0,03 & 0,05 \\
\hline$P$ value & 0,56 & ** & ** & ** & 0,27 & 0,88 & 0,91 & 0,96 & 0,67 & 0,47 & 0,06 \\
\hline
\end{tabular}

$* \mathrm{p}<.05$

$* * \mathrm{p}<.01$.

Table 2. The mean values and standard deviations for transportation ( $\mathrm{mm}$ ) after instrumentation at each level

\begin{tabular}{|c|c|c|c|c|c|c|c|c|c|c|c|}
\hline \multirow{2}{*}{ Twisted File } & \multicolumn{11}{|c|}{ Transportation (mm from the apex) } \\
\hline & 0 & 1 & 2 & 3 & 4 & 5 & 6 & 7 & 8 & 9 & 10 \\
\hline Mean & 0,04 & 0,04 & 0,05 & 0,04 & 0,05 & 0,11 & 0,22 & 0,15 & 0,06 & 0,05 & 0,07 \\
\hline SD & 0,03 & 0,03 & 0,04 & 0,04 & 0,03 & 0,05 & 0,05 & 0,06 & 0,05 & 0,04 & 0,06 \\
\hline $\begin{array}{l}\text { RaCe } \\
\text { Mean }\end{array}$ & 0,05 & 0,05 & 0,05 & 0,05 & 0,05 & 0,17 & 0,27 & 0,20 & 0,07 & 0,06 & 0,08 \\
\hline SD & 0,04 & 0,04 & 0,04 & 0,04 & 0,04 & 0,07 & 0,05 & 0,07 & 0,05 & 0,04 & 0,06 \\
\hline$P$ value & 0,52 & 0,48 & 0,89 & 0,65 & 0,96 & $*$ & $*$ & 0,08 & 0,45 & 0,87 & 0,56 \\
\hline
\end{tabular}


Table 3. The mean values and standard deviations of the centering ratio (ability) for each leveL

\begin{tabular}{|c|c|c|c|c|c|c|c|c|c|c|c|}
\hline \multirow{2}{*}{$\begin{array}{l}\text { Twisted } \\
\text { File }\end{array}$} & \multicolumn{11}{|c|}{ Centring ability ( $\mathrm{mm}$ from the apex) } \\
\hline & 0 & 1 & 2 & 3 & 4 & 5 & 6 & 7 & 8 & 9 & 10 \\
\hline Mean & 0,60 & 0,67 & 0,65 & 0,69 & 0,70 & 0,50 & 0,21 & 0,44 & 0,75 & 0,80 & 0,74 \\
\hline SD & 0,20 & 0,21 & 0,26 & 0,25 & 0,19 & 0,19 & 0,10 & 0,17 & 0,18 & 0,13 & 0,19 \\
\hline $\begin{array}{l}\text { RaCe } \\
\text { Mean }\end{array}$ & 0,56 & 0,68 & 0,71 & 0,70 & 0,74 & 0,39 & 0,18 & 0,38 & 0,73 & 0,80 & 0,74 \\
\hline SD & 0,18 & 0,26 & 0,22 & 0,04 & 0,17 & 0,17 & 0,09 & 0,16 & 0,16 & 0,13 & 0,15 \\
\hline $\mathrm{P}$ value & 0,54 & 0,90 & 0,53 & 0,93 & 0,58 & 0,11 & 0,40 & 0,34 & 0,65 & 1,00 & 0,92 \\
\hline
\end{tabular}

\section{DISCUSSION}

Comparing the shaping ability of root canal instruments requires the evaluation of diverse design aspects and their complex interrelationships. These design parameters include cross-sectional design, chip removal capacity, metallurgical properties, and surface treatment of the instruments. ${ }^{5,17}$ The purpose of this study was to compare the shaping ability of TF and $\mathrm{RaCe}$ instrument systems. These systems have triangular cross sections but differences in other aspects such as surface treatment and flute design.

The results of the present study revealed significant differences between these systems with respect to their shaping ability. Overall, RaCe instruments removed more resin compared to TF. This difference can be attributed to the sharp cutting blades of RaCe. ${ }^{17}$ In addition, the RaCe instrument showed more material removal on the inner side of the coronal curvature and the outer side of the apical curvature. This finding suggests that the $\mathrm{RaCe}$ instrument might be stiffer and has a tendency for straightening. Our finding is aligned with a previous study by Aydin et $\mathrm{al}^{18}$ who compared the shaping ability of RaCe and Hero Shaper instruments with triangular cross-sections. Their study reported that RaCe instruments removed more resin from the outside of the curvature at the apical third.

Other key parameters used to evaluate shaping are to protect the curvature of the canal and to maintain good centering ability. ${ }^{3}$ In this study, at the end point of the root canals, both TF and RaCe groups showed favorable results. No ledge or zip formation occurred at the end-point of preparations with either group. Root canals prepared by both RaCe and TF files maintained their original curved shape at the apical section. In addition, the apical preparations resulted in only minor deviations from the main axis showing good centering ability for both systems.
According to the Glossary of Endodontic Terms of the American Association of Endodontists, canal transportation is defined as follows: ${ }^{19}$ 'Removal of canal wall structure on the outside curve in the apical half of the canal due to the tendency of files to restore themselves to their original linear shape during canal preparation; may lead to ledge formation and possible perforation.' As a result of this asymmetrical material removal during shaping, the long axis of the curved root canal will be displaced and the angle of curvature will decrease, resulting in straightening of the original curvature of the root canal. The following aspects are associated with an increased risk of canal transportation: insufficiently designed access cavities, alloy (stainless-steel versus nickel-titanium) and design features (cross-sectional design, number of flutes, and rake angle) of root canal instruments, use of instruments with sharp cutting tips, use of inflexible instruments in sizes above \#20 in severely curved root canals, forcing the instrument into the root canal (that is, to avoid the use of a crown-down approach in curved canals), instrumentation technique (step-down approaches or balanced-force technique versus a stepback or a standardized technique), insufficient irrigation during mechanical enlargement, operatorrelated factors (e.g. experience) and degree of canal curvature and radius of the curvature. ${ }^{17,20-22}$

In the present study, the canals prepared by RaCe instruments showed more canal transportation than TF instruments in the direction of the inner canal wall at the middle section (5 and $6 \mathrm{~mm}$ from the apex). This finding is confirmed in other recent studies, which indicate significantly more canal transportation with RaCe files, compared with Twisted File and Twisted File Adaptive. ${ }^{23,24}$ The reduced root canal transportation of TF files can be explained by the high flexibility of these instruments. This superior flexibility, enabled through R-phase technology, 
reduces the risk of root canal transportation when preparing curved canals. ${ }^{25}$

At the coronal section, RaCe instruments removed more resin compared to TF. This is due to the larger taper and larger size of the $\mathrm{RaCe}$ instruments used at the canal orifice. These features facilitates irrigation of root canals. When comparing the shaping ability of different root canal instruments, it is important to have similar diameters for apical preparations. ${ }^{26}$ Thus, final apical preparation diameter was 0.04 taper, size \#25 in all investigated groups of the present study.

In conclusion, RaCe instruments removed more resin from the outside of the apical curvature and from the inner side of the coronal curvature. RaCe also showed more canal transportation at the coronal curvature. Both RaCe and TF instruments showed favorable centering ability and fewer aberrations. No instrument fractured but some deformations were observed for both systems. The TF system was favorable in its flexibility while the RaCe system was sharp and allowed for more resin removable from the canal walls. These results suggest that hybrid use of these instruments can be beneficial when preparing more conical canals with less canal transportation77.

In order to obtain identical samples with a standard canal length, location, and radius of curvature, simulated curved root canals were used instead of real teeth in the present study. Although the simulated resin canal does not reflect the action of the instruments in root canals of real teeth, it allows direct comparison of the shaping ability of different instruments. $^{27}$ While the techniques using superimposition of pre- and post-operative outlines can easily be applied to real teeth models, ${ }^{5}$ the microhardness of resin is different from that of natural teeth, and heat generated during preparation may soften the resin. ${ }^{28,29}$ Thus, the simulation-based experimental models have limitations and should be extrapolated to real teeth with caution. Further studies in extracted teeth and clinical studies on active patients should be conducted.

\section{CONCLUSIONS}

RaCe instruments removed more resin from the outside of the apical curvature and from the inner side of the coronal curvature compared to TF. In addition, mean transportation amount was significantly high for
RaCe in middle section (i.e., coronal curvature). Regarding canal centering ability, however, both instruments retained original canal geometry and performed similarly.

Conflict of Interest: No author of this article has a conflict of interest, including specific financial interests, relationships, and/or affiliations relevant to the subject or materials included in the manuscript.

Senay Yaşar: ORCID ID: 0000-0003-4477-406X

Şeyda Erşahan: ORCID ID: 0000-0002-0354-5108

Cumhur Aydın: ORCID ID: 0000-0003-3009-0548

\section{REFERENCES}

1. Schilder $\mathrm{H}$. Cleaning and shaping the root canal. Dent Clin North Am 1974;18:269-96.

2. Esposito PT, Cunningham CJ. A comparison of canal preparation with nickel-titanium and stainless steel instruments. J Endod 1995;21:173-6.

3. Gergi R, Osta N, Bourbouze G, Zgheib C, ArbabChirani R, Naaman A. Effects of three nickel titanium instrument systems on root canal geometry assessed by micro-computed tomography. Int Endod J 2015;48:162-70.

4. Koch K, Brave D. Real world endo: design features of rotary files and how they affect clinical performance. Oral Health 2002;92:39-49.

5. Hulsmann M, Peters OA, Dummer PMH. Mechanical preparation of root canals: shaping goals, techniques and means. Endod Topics 2005;10:3076.

6. Peters OA. Current challenges and concepts in the preparation of root canal systems: a review. J Endod 2004;30:559-67.

7. Gambarini G, Testarelli L, De Luca M, Milana V, Plotino G, Grande NM, et al. The influence of three different instrumentation techniques on the incidence of postoperative pain after endodontic treatment. Ann Stomatol (Roma) 2013;4:152-5.

8. Pagliosa A, Sousa-Neto MD, Versiani MA, RaucciNeto W, Silva-Sousa YT, Alfredo E. Computed tomography evaluation of rotary systems on the root canal transportation and centering ability. Brazilian Oral Res 2015;29.

9. Gambarini G, Grande NM, Plotino G, Somma F, Garala M, De Luca M, et al. Fatigue resistance of engine-driven rotary nickel-titanium instruments produced by new manufacturing methods. J Endod 2008;34:1003-5. 
10. Larsen M, Watanabe I, Glickman GN, He J. Cyclic fatigue analysis of a new generation of nickel titanium rotary instruments. J Endod 2009;35: 401-3.

11. Ceyhanli KT, Erdilek N, Tatar I, Çetintav B. Comparative micro-computed tomography evaluation of apical root canal transportation with the use of ProTaper, RaCe and Safesider systems in human teeth. Aust Endod J 2014;40:12-6.

12. Nabavizadeh $M$, Abbaszadegan A, Khojastepour $L$, Amirhosseini M, Kiani E. A comparison of apical transportation in severely curved canals by Reciproc and BioRaCe systems. Iran Endod J 2014;9:117-22.

13. Pasqualini $D$, Alovisi M, Cemenasco A, Mancini $L$, Paolino DS, Bianchi CC, et al. Micro-computed tomography evaluation of ProTaper Next and BioRaCe shaping outcomes in maxillary first molar curved canals. J Endod 2015;41:1706-10.

14. Schneider SW. A comparison of canal preparations in straight and curved root canals. Oral Surg Oral Med Oral Pathol Oral Radiol Endod 1971;32:271-5.

15. Thompson SA, Dummer PMH. Shaping ability of Hero 642 rotary nickel-titanium instruments in simulated root canals: part 2. Int Endod J 2000;33:255-61.

16. Paque F, Laib A, Gautschi H, Zehnder M. Hardtissue debris accumulation analysis by highresolution computed tomography scans. J Endod 2009;35:1044-7.

17. Schafer $E$, Oitzinger $M$. Cutting efficiency of five different types of rotary nickel-titanium instruments. J Endod 2008;34:198-200.

18. Aydin C, Inan U, Yasar S, Bulucu B, Tunca YM. Comparison of shaping ability of RaCe and Hero Shaper instruments in simulated curved canals. Oral Surg Oral Med Oral Pathol Oral Radiol Endod 2008;105:e92-7.

19. American Association of Endodontists. Glossary of Endodontic Terms. 7 ed. Chicago; AAE: 2003.

20. Jafarzadeh $H$, Abbott PV. Ledge formation: review of a great challenge in endodontics. J Endod 2007:33:1155-62.

21. Schafer E. Relationship between design features of endodontic instruments and their properties. Part 2: instrumentation of curved canals. J Endod 1999:25:56-9.

22. Lam TV, Lewis DJ, Atkins DR, Macfarlane RH, Clarkson RM, Whitehead MG, Brockhurst PJ, Moule
AJ. Changes in root canal morphology in simulated curved canals over-instrumented with a variety of stainless steel and nickel titanium files. Aust Dent J 1999:44:12-9.

23. Andradw-Junior CV, Neto ND, Rodrigues RC, Antunes HS, Porpino MT, Carvalhal JA, Armada L. Transportation assessment in simulated curved canals after preparation with Twisted File Adaptive and BT-Race instruments. J Clin Exp Dent 2017;1:e1136-e1140.

24. Honardar K, Assadian H, Shahab S, Jafari Z, Kazemi A, Nazarimoghaddam K, Kharrazifard MJ, Labbaf $H$. Cone-beam computed tomographic assessment of canal centering ability and transportation after preparation with Twisted File and Bio RaCe instrumentation. J Dent (Tehran) 2014;11:440-6.

25. Schafer E, Dzepina A, Danesh G. Bending properties of rotary nickel-titanium instruments. Oral Surg Oral Med Oral Path Oral Radiol Endod 2003;96:757-63.

26. Bergmans L, Van Cleynenbreugel J, Beullens M, Wevers M, Van Meerbeek B, Lambrechts P. Progressive versus constant tapered shaft design using $\mathrm{NiTi}$ rotary instruments. Int Endod J 2003;36:288-95.

27. Schafer E, Tepel J, Hoppe W. Properties of endodontic hand instruments used in rotary motion. Part 2. Instrumentation of curved canals. J Endod 1995;21:493-7.

28. Kum KY, Spanberg L, Cha BY, Young J, SeungJong L, Chan-Young L. Shaping ability of three ProFile rotary instrumentation techniques in simulated resin root canals. J Endod 2000;26:71923.

29. Gündoğdu EC, Doğanay E, Arslan H. Nikel titanium aletlerin kırılmalrının sebep ve çözümlerine yönelik anket çalışması. Atatürk Univ Diş Hek Fak Derg 2017;27:130-8.

\section{Yazışma Adresi}

Seyda Ersahan, DDS, PhD

İstanbul Medipol Üniversitesi, Diş Hekimliği

Fakültesi, Esenler Hastanesi,

Birlik Mah. Bahçeler Cad. No: 5 Esenler, İstanbul, TURKEY

Tel: +90 5324054088

e-mail: seydaersahan@hotmail.com 